\title{
Reinforcing Character education on the Perspective of Islam Education: Analyzing inhibiting and supporting factors
}

\author{
a,1 Anaas Tri Ridlo Dina Yuliana; ${ }^{\text {a,b,2 }}$ Zalik Nuryana; ${ }^{\text {a,3 }}$ Tri Yaumil Falikah; ${ }^{\text {a,4 }}$ Fandi Akhmad
}

\begin{abstract}
Teacher's role in educating students is becoming more complex recently. It should not only educate students to be intelligent but also have a character. This is a qualitative field research with study case method. The data collection techniques that were utilized were observation, interview, documentation and triangulation. The data analysis consisted of data collection, reduction and presentation and drawing conclusion. The objectives of this research are to analyze the implementation of streghtening of students' character education, inhibiting and supporting factors, and teacher's role in reinforcing students' character education seen from the perspective of Islam education at SMK Muhammadiyah 1 Wates. The finding indicates that the implementation of the reinforcing of students'character education had been done by applying programs of prosperous, religious and discipline. The obstacles of implementation are miscommunication, difference of character understanding adaptation, family background, and age. Meanwhile, supporting factors such as Islamic human resource, school societies' commitment, professionalism, sincere and loyal work. Teachers'role in reinforcing students' character education seen from perspective of Islam education by applying tadzkiroh model.
\end{abstract}

Keywords: Teachers' Role, Character Education Strengtening, Islam Education

${ }^{\mathrm{a}}$ Faculty of Islamic Studies, Universitas Ahmad Dahlan, Indonesia

${ }^{\mathrm{b}}$ School of Education and Science, Nanjing Normal University, China

$1 \quad$ anaas.yuliana@pai.uad.ac.id; 2 zalik.nuryana@pai.uad.ac.id; 3 tri.falikhah@pai.uad.ac.id; fandi.akhmad@pai.uad.ac.id

Correspondent: zalik.nuryana@pai.uad.ac.id

Received: , Accepted:

\section{INTRODUCTION}

Education has an influence as a media that develops and improve an individual's 
potential to be qualified. It is performed through a process of individual learning and formal or informal education institution. Education system has transformed following from conservative era development that has emphasized on the aspect of knowledge which has entered developed and modern technology era that has implemented digital-based method (Darimi, 2017). The more open and borderless world or so-called globalization era raise many new issues, especially regarding students' character. Entering millennium year, issues regarding students' character and moral are quite concerning. This character and moral crisis can push students who don't have character establishment fall to promiscuity, juvenile delinquency, pornography, pornoaction, illegal drugs misues, and even criminal actions (Ramdhani, 2014).

The government as the main authority holder of education policy maker has designed curriculum which has been adjusted to education world development by considering various aspects of internal and external needs. In fact, there are pros and contras of the legalization of curriculum adjustment in the societies and school societies, for example teachers and students. Some previous education curricula that had been prevailed by the government focused on cognitive or knowledge aspect. For example, in the curriculum 1994, Competence-Based Curriculum and Education Unit Level Curriculum in which school more focused on academic achievement and specific skill in vocational school without cognitive aspect balance. It happens because of school thinking pattern as a place to obtain knowledge and consider education on cognitive aspect implemented in character education has been performed at home through parents' guidance and surrounding. Whereas, school holds crucial role to reinforce character education (Islam, 2017).

In 2013, the government issued the policy of curriculum 2013 implementation to respond education world which includes all aspects such as cognitive, psychomotor, and cognitive propotionally (Fahrudin et al., 2017). Curriculum 2013 has integrative thematic essence by combining 4 aspects to become core competences such as spiritual, social, knowledge, and skill aspects. In order to achieve the objective of this curriculum implementation, teachers hold an important role as a leader or motivator for students to develop self competence optimally. It is expected that effective learning performed by teachers can build students to have strong and positive character after they study in the education institution (Ainiyah, 2013). Therefore, at least teacher as the prime mover motor of character education design an interactive classroombased education design. Besides, school culture should not support moral messages but also character education in real. Furthermore, in order to reinforce character education on students, it is expected that teachers identify recent problems related to moral crisis and determine an 
appropriate method so that character education will be achieved.

The importance of character education has become one of hot discussion materials in the education world until today (Yuliana \& Wurinta, 2020). Character crisis issues and the terms accompany them such as morality, ethic, and characters indicate symptons which affect intolerance, violences, threats, habits, and other desctructive behaviors. Although since the New Orde, the government had implemented education and development of character through Pancasila and Civic Education with enough significant portion, however, character education was still ideological and more oriented on the fidelity towards the government dominantly maintained national stability (Hamdani, 2014). The effect of this character education building could overthrow the government's authority on the citizens. Even at school character education was merely directed to students and caused them to experience psychological stress and feeling of burden. As a result, it has potential to cause a new problem of moral disintegration and juvenile delinquency. As what can be generallt seen in schools at present that character education is only limited in form of lesson. Finally, the objective of character education which emphasizes on religious character building will never be achieved effectively.

Character education seen from the Islam education point of view is understood as a moral education. In the curriculum of education in Indonesia, the implementation of moral education is performed through Islam Education Lesson (PAI) through theory, practice and school culture. In this matter, formal education institution educates students to understand textual and contextual character development. Religious character values are embedded by teachers through both classroom learning process or outside. Besides, the context of character values building is applicable through various superior programs of education institution concerning moral education as Islamic character education development. It becomes a challenge for teachers because the gap between moral education in religion subject and other general subjects are far enough in the present learning system. Therefore, there should be teachers' best proficiency and competence in undergoing comprehensive and integrated learning process which are oriented on moral education in each material taught (Herwina, 2018).

To date, moral education which is taught at school only emphasizes on science without real practice in daily life. For example, education on theorem of adultery prohibition and any action drives to adultery is only theoretically understood by only knowing and memorizing its prohibition theorem, but in practice many students do actions which direct to adultery action, such as dating (Pawitasari et al., 2015). In order to find out the achievement of religious character education, it cannot only be observed but also identified and explored deeply through 
a case study.

The researcher is interested in performing a research concerning "Teachers' Role in Reinforcing Students' Character Education on the Perspective of Islam Education in SMK (Vocational High School) Muhammadiyah 1 Wates". SMK Muhammadiyah 1 Wates is one of private schools in Kulon Progo regency which prepares its graduates to become competitive in the real world of work, not only smart in theory and professional in skill but also have character. Besides, SMK Muhammadiyah 1 Wates is selected as a model of Prosperous School in which all school members make exosystem or school environment which pays attention and support students' mental health related character building. This research is aimed to 1) analyze the implementation of students' character education; 2) analyze factors which hamper and support the process of students' character education reinforcement; and 3) and analyze teachers' role in reinforcing students' character education on the perspective of Islam education in SMK Muhammadiyah 1 Wates.

\section{METHODS}

This research was executed in SMK Muhammadiyah 1 Wates. It is a field research related to "Teachers' role in Strengtening Students' Character Education on the Perspective of Islam Education in SMK Muhammadiyah 1 Wates." The research methodology which was utilized was qualitative type to obtain a knowledge on character education through teachers' contribution themselves as a major phenomena that needs exploration and understanding [10]. The case study was the method which was utilized in this research.

A case study is an in-depth exploration of bound system such as activities, events, process, or individuals based on data collection with a certain limit in the matters of time, place, or some physical limitation. In practice, case study has various types depend on the research objectives themselves, such as figuring, explaining, exploring, or comparing among cases. By considering the context and objectives of the research, the authors choose to use collective case study in which it enables them to perform cross-case analysis in a research context. A collective case study involves a study with more than one cases to "investigate a phenomenon, population, or general condition. Miles and Huberman (1994) opined that collective case study provides them with a guarantee that a case is "not fully special". Furthermore, studying many cases enable researchers to see the process and result of al cases comprehensively and obtain deeper understanding in stronger description and explanation (Creswell, 2012).

The data collection techniques utilized by the researcher were observation, interview, 
documentation, and triangulation. A triangulation in data collection technique is a technique which combines various data collection techniques and existing sources. The researcher sutilized different data collection technique to get data from the same source. The researchers utilized participative observation, in-depth interview, and documentation for same data source. While, the source triangulation was to get data from difference souces with same technique (Sugiyono, 2013).

The data analysis is done by organizing data into category, elaborating it into units, synthesizing, arranging into patterns, selecting which is important and will be learnt, and making a conclusion to be understood by theirselves or other people (Sugiyono, 2013). The data analysis utilized interactive data analysis which took place continuously until it completed and saturated. The data analysis which was utilized was guided on Miles and Huberman's model which consisted of data collection, reduction, presentation and conclusion (Sugiyono, 2013).

\section{RESULTS AND DISCUSSION}

\section{The Implementation of Students' Character Education}

Character has an almost similar meaning with character and moral which mean habit or custom (Nur, 2013). Imam Al-Ghazali defined character was closely related to moral, which is human'spontananity to behave and act as integrated within themselves (Aeni, 2014). While according to Thomas Lickona, character education is defined as knowing the good, feeling the good, and doing the good (Setiawan, 2013). The nature of character education is not only related to true or false, but also how inculcate good habit in students so that they have high understanding, awareness, concern and commitment to implement goodness in daily life. In this case, character or noble character possessed by student cannot be achieved as such without a training of character education reinforcement at school. The implementation of students' character education in SMK Muhammadiyah 1 Wates was performed by applying some programs through prosperous, religious and discipline school programs.

\section{Prosperous School Program}

SMK Muhammadiyah 1 Wates in Kulon Progo is the only one vocational high school which has been chosen as the model of Prosperous School in which all school societies cooperate to support each other, give positive appreciation and motivation so that students grow optimally with a tough character, are able to know their personal potential, be productive and able to contribute. This prosperous school program does not only act if there is a problem, but 
it is preventive by building a positive environment in school environment or in the classroom so students feel humanized and respected.

In this program, the school principal formed a pioneer team of prosperous school that included School Principal, Vice School Principal of Student Affairs, Vice School Principal of Public Relation, Vice School Principal of ISMUBA affairs (Al-Islam, Muhammadiyah affairs, and Arabic), Counceling Guidance Teacher and Head of Administration. While on students' aspects, the school formed peer counselor or students who have positive character to become peer counselors. The task of prosperous pioneers as a character mover gives an example and guide students. Besides, the task of peer counselors are also important to indentify problems faced by students around them. When students have a problem, the first person to talk is peer, not older people (Widayat, 2016). The tasks of a peer counsellor are to become a good listerner, identify problem, entertain, and give solution. However, if the problem is complex and peer counsellors cannot solve it, they will direct it to the pioneer team of prosperous school. In this case, the pioneer team performs routine appointment coordination with peer counsellors once in three month at the maximum and it can also be performed insidentally or as necessary.

In this school program, the pioneer team coordinates with students' parents by holding parenting program. This activity is aimed to provide knowledge and skill of students' parents in educating their children at home with a good character ground. Besides, this activity is a medium for sharing related to program plan and objective that will be achieved.

\section{Religious Program}

Religious program should be held at school and implemented continuously as an effort to reinforce students' character education at present or in the future (Suryanti \& Widayanti, 2018). SMK Muhammadiyah 1 Wates applied the following religious programs: Inculcation of tadarus Al-Qur'an before starting the lesson and led by a teacher; (b) Inculcation of sholat in congregation (dhur,zuhr and asr prayer) in school mosque; (c) Inculcation of hadist reading and its meaning and explanation after dhur prayer. The inculcation is guided by teachers; (d) TPA or iqro and Al-Qur'an reading guidance for students who have not read AlQur'an fluently; (e) Art extracurricular of reading Qur'an for students who read Al-Quran fluently' (f) A study for female students is done when Friday Prayer. When male students perform duty of Friday prayer, female students perform a feminine study guided by female teacher who teaches ISMUBA subject; (g) However, they also give an opportunity to female students if they want to give a study. It trains them to be confident, show up and learn to deliver 
a knowledge although it is only a verse; (h) A compulsory recitation to all students is held once a month; (i) An Islamic worship monitoring book for students at home. It is reported to ISMUBA teacher once a week for evaluation.

Character values are integrated through those religious program activities which involve all school societies. The religious program encourages students to have religious characters. These characters reflect their obedience towards the one Almighty God as manifested in performing Allah's orders and staying away from all forbidden acts. Besides, individuals who have religious characters put forward tolerant and responsible attitudes and have a strong faith and are spared from despicable deeds.

\section{Discipline Program}

One of efforts to improve students' discipline attitude by performing briefing for students at school. Briefing activity is an activity which is aimed to build a discipline character (Warsito, 2017). SMK Muhammadiyah 1 Wates applies discipline program by doing morning afternoon briefing. Many instructions or advices are obtained by students in briefing. Those help directing students to be better.

The morning briefing is performed before students entering the classroom, which is from 06.45 to 07.00 AM WIB. All students, teacher and employees perform morning briefing such as students' presence, tidiness, and readiness for study and give motivation. If there are students who come late, discipline team will give a warning and write their names as an evaluation in the future. Besides giving a warning and writing their names, the team also gives a sanction. The sanction is based on the instruction of discipline team. The sanctions are reading Al-Quran, memorizing Qu'ranic letters, optional letters in Al-Qur'an, and hadists studied by them. The afternoon briefing is performed before students go home. It is done to control their tidiness and attendance, whether there are students who skip the class or not. If there is a student who skip the class, the discipline team will take note and follow up on the next day. The continuous briefing every morning and afternonn as performed by the school will shape students' discipline character. 


\section{Reinforcement}

\section{Inhibiting factors}

The implementation of students' character education in SMK Muhammadiyah 1 Wates does not always run well. It means that there are various factors which become its inhibitors. The inhibition which emerges during the implementation of students' character education reinforcement in SMK Muhammadiyah 1 Wates is misscommunication one teacher and another, and a teacher and student, and a student and another. The other inhibition is adaptation difference on understanding character. Besides, various family and age backgrounds are also inhibiting factors in implementing students' character education reinforcement.

\section{Supporting Factors}

There is a supporting factor in each inhibition in the implementation of students' character education reinforcement in SMK Muhammadiyah 1 Wates. The supporting factors are Islamic human resource, commitment of school societies to be better, and upholding professionalism with a good coordination and organization. Besides, the school societies work sincerely and loyally. The supporting factors possessed by the school can be optimized to minimize the inhibitions which exist so that the implementation of character education can run well. Therefore, the character values are embedded within the students themselves and they have a strong character and noble moral.

\section{Teachers' Roles in the Reinforcement of Students' Character Education from the Perspective of Islamic Education}

The roles of teachers in education students are becoming complex. It does not only make them intelligent but also educate them to have good and noble character (Rostikawati et al., 2020). A teacher holds a control on the creation of students' character so that his role is crucial. Teachers of SMK Muhammadiyah 1 Wates apply tadzkiroh model in the implementation of students' character education reinforcement from the perspective of Islam education. The model which was presented by Abdul Majid and Dian Andayani can be seen as an Islam education model to guide students so that they fertilize, maintain, and grow faith to get a concrete form, which is good deed framed with sincerity of praying and creating sincere and pleased heart in the provision of Allah (Majid \& Andayani, 2012).

Etymologically, tadzkiroh comes from Arabic 'dzakkara' which means remember and 'tadzkiroh' is a warning. What is meant by tadzkiroh according to Majid and Andayani is a model brought down from an Islamic education theory. See table 1. 
Table 1. TADZKIRAH Explanation

\begin{tabular}{|c|c|}
\hline \multirow[t]{9}{*}{ TADZKIROH } & $\mathrm{T}=$ Tunjukkan Teladan (Show an uswah hasanah) \\
\hline & $\mathrm{A}=$ Arahkan (Drive and give a guidance) \\
\hline & $\mathrm{D}=$ Dorongan (Encouragement give a motivation) \\
\hline & Z = Zakiyah (pure/clean-embed sincere intention) \\
\hline & $\mathrm{K}=$ Kontinuitas (Continuity (Inculcation process to learn, act and behave) \\
\hline & $\mathrm{I}=$ Ingatkan $($ Remind $)$ \\
\hline & $\mathrm{R}=$ Repitisi (Repetition) \\
\hline & $0=$ Organisasikan (Organize) \\
\hline & $\mathrm{H}=$ Hati (Heart/touch their heart) \\
\hline
\end{tabular}

\section{T = Tunjukkan Teladan (Show an uswah hasanah)}

An uswah hasanah concept has been provided by Allah by sending Prophet Muhammad SAW as a good model for Islam people along the history and for all humans everywhere. "Assuredly there hath been for you: in the apostle of Allah and excellent pattern for him who hoped in Allah and the Last Day and remembereth Allah much.” (QS. Al-Ahzab: 21). This excellent pattersn should be fertilized and maintained. Teachers should have a certain character because they are the excellent pattern for students at school. A teacher's exellemt pattern is a method which is proven to be successful to preparea and shape stuents' character and will give positive values for students' character (Ninsiana, 2016).

Teachers of SMK Muhammadiyah 1 Wates give an uswah hasanah for students by coming earlier before school time, entering classroom on time, and being discipline in submitting administioanl tasks. By showing a good example of discipline, it is expected that students will imitate it (Anaas Tri Ridlo Dina Yuliana, 2017). Other excellent patterns given by teachers of SMK Muhammadiyah 1 Wates are dressing neatlyas Islam Sharia, good words and actions, and performing sholat/prayer in congregation (dhur, zuhr and asr prayer) at school mosque. Besides, teachers also inculcate an excellent patterns such as 5S (Senyum, Salam, Sapa, Sopan and Santun) or Smile, Greeting, and Polite to students. When a gives an excellent 
pattern to students, they have a figure that becomes a good example so that they have noble and positive character.

\section{$A=$ Arahkan (Drive and give a guidance)}

"So be steadfast in faith in all uprightness 'O Prophet'- the natural Way of Allah which He has instilled in 'all' people. Let ther no change in this creationof Allah..." (QS. Ar-Rum: 30). Basically, children have been created by Allah as their nature, which tends to a truth. Therefoe, when there is a students who deviates from the truth, a teacher must give a guidance.

A guidance to students is absolutely performed by teachers inside or outside the classroom to direct them on good and bad, true or false and things that must be obeyed or forbidden. Teachers of SMK Muhammadiyah 1 Wates performed the development by providing an explanation, direction, and discussions related to self adaptation, teenager social ethics, career development related to students' character building. Those things were performed to avoid desctructive behaviors. However, the development can be done when there is a violation or problem. Teachers can reprimand students who violate or behave deviantly. Furthermore, teachers find the causes of the problem and give suggestion and guidance to students so they change their behaviors. The guidance provided by teachers can shape and reinforce students' character. In this case, maintaining good relationship between teachers and students' parents and students themselves is equally important because advice will be easily accepted if they have good relationship.

\section{D = Dorongan (Encouragement give a motivation)}

Motivating children is an activity to encourage them so they are willing to perform activities or action which are expected by parents or teachers. Al-Ghazali, in his book Tahdzib Al-Akhlak wa Mu'alajat Amradh al-Qulub, stated that when a child gets a compliment and he should be given a gift or insentive with something that makes happy or give a praise infront of people (Majid \& Andayani, 2012). Teachers of SMK Muhammadiyah 1 wates always give motivation to students. During a teaching-learning activity, the teacher always gives an encouragement to students to study and be enthusiastic to undergo their lives. Besides, teachers also give a present to high-achieving student and an appreciation to students who haven't achieved it. When there are students who indicate good characters, teachers will be praised. Therefore, they will always be enthusiastic and encouraged to do positive actions and goodness. 


\section{$\mathrm{Z}=$ Zakiyah (pure/clean-embed sincere intention)}

"Trully he succeeds that purifies it, and he fails that corrupts it! (QS. Asy-Syams: 910). Islam orders the people to purify themselves to become a lucky individual. The ability toact wara' (refrain), maintain self-purity and clean the soul from sins will create a clean heart with a sincere intention and everything they do only hopes for Allah's pleasure (sincere). A sincere feeling should be embedded by a teacher towards students in studying, behaving, and doing small actions. If the feeling has grown, the sincerity will give a big power to change students' behaviour and character. Teachers of SMK Muhammadiyah 1 Wates always inculcate a sincere intention to students in the process of learning, behaviour, and being charitable. A sincere intention and hope for Allah's pleasure which is inculcated in students because they are still unstable, therefore they need character education reinforcement by embedding sincerity. Thus, students' actions are based on a sincere intention and a clean heart.

\section{$\mathrm{K}=$ Kontinuitas (Continuity (Inculcation process to learn, act and behave)}

Al-Quran makes inculcation as an education method which changes good characteristics to become a habit. Al-Quran uses it gradually in creating good habit and eliminate an individual's bad habit.In this relationship, Prophet instructed parents to ask their children performing sholat when they are 7 years old. Then, they are allowed to beat them until the children are 10 years old and have not performed sholat. In order to create good habit, guidance, practice and Allah's rules study are done (Majid \& Andayani, 2012). The process of incolculation in school environment should be started and embedded to students because it is very effective in the education which is connected to moral. Teachers of SMK Muhammadiyah 1 Wates perform incolculation process towards students by providing a guidance and trainings in praying. Besides, they incolculate by studying Allah's rule related to the implementation of whatever is instructed by Allah and how to stay away from His prohibition. If the process of studying, behaving and doing good things have been embedded in students, they will never feek burdensome to pray and they will easily do good things. Therefore, the actions performed by students are not temporary but become daily habit (Suryadarma \& Haq, 2015).

\section{$\mathrm{K}=$ Kontinuitas (Continuity (Inculcation process to learn, act and behave)}

The word "remind" here means reminding goodness and avoiding any action which is 
prohibited by syariah Islam (Fitri, 2018). In the learning process, teachers of SMK Muhammadiyah 1 Wates always remind their students to perform sholat on time, be filial towards parents, help each other and do well to each other. When there is a student who does deviance, they remind him to not repeat it. Besides, teachers try to remind them that Allah always monitor us and He knows what is hidden although it is implied in their heart. So they will always remember Allah. In the Qur'an on surah Ar-Ra'd verse 28, it's explained that when remember Allah, the heart will be in peaceful heart. Therefore, they will be spared from despicable acts and always try to perform praiseworthy acts.

\section{$\mathbf{R}=$ Repitisi (Repetition)}

Aisyah RA., said "Prophet SAW says a word three times so his hearing understand. When he came to a community, he greeted 3 times" (HR. Bukhari). The objectives of repetition is to remember, understand the words and becoming familiar (Aeni, 2014). An effective education is done repetitively so that children understand. Lesson or advice should be performed repeteadly so children can understand. Also, character reinforcement should be done repetitively to make children understand and familiar so that they have a tough and noble character. Teachers of SMK Muhammadiyah 1 Wates do repetition on character education by always supporting and giving a good example to students, always give a guidance and movitation, and remind them to perform good things. Teachers always repeat character education reinforcement towards students with a sincere and patient heart. Therefore they will understand and be familiar with goodthings and shape and reinforce their character.

\section{$\mathbf{O}=$ Organisasikan (Organize)}

"Organize" means teachers should be able to organize knowledge and experience obtained by students outside and inside the school through teaching learning activity. Systematic organizing assists teachers to get correct information and teacher can deliver information well. The information will become a feedback (Ridwan, 2017). Teachers of SMK Muhammadiyah 1 Wates organizes based on the advantage to students as an education process to become individuals who are ready toface life with noble characters. This organizing includes planning, implementation and valuation. In this case, teachers do strategic steps such as from easy to difficult, from simple to complex and from concrete to abstract.Good organizing will enable teachers to perform evaluation and students' character education reinforcement. 


\section{H = Hati (Heart/touch their heart)}

Somebody said that heart is like a container. Infidel person's heart is like an upside down container so that goodness cannot enter. Faithful people's heart is like a great and stabile container so that good ness will enter (Hasnawati, 2020). What should we know and realize that an individual's faith is higher or lower, so we need to touch their heart to reinforce. On this stage, the instrument is heart. So manager the heart well because actions come from the heart. Teachers of SMK Muhammadiyah 1 Wates always try manage their heart before they act. After the heart is managed, teachers perform education process in building students' character by touching their heart. It is aimed to succeed the students' character education reinforcement because it is delivered from heart to heart. In this process, students manage their heart to determine good or bad action, so it will create good action which comes from the students' heart.

\section{CONCLUSIONS}

The character possessed by students cannot be merely achieved without the development of character education at school. The implementation of students' character education reinforcement in SMK Muhammadiyah 1 Wates is performed by applying some programs such as through prosperous school program, religious, and discipline. There are some obstacles which emerge such as miss communication between teacher and another, teacher and student, and student and another; different character understanding adaptation, and family and age background. There are always supporting factors of each obstacle in the implementation of students' character education. Those supporting factors are Islamic human resource, school societies' commitment to be better, upholding professionality and good coordination and organization, work sincerely and loyally. The supporting factors possessed by the school are optimized to minimize the existing obstacle so that the implementation of character education runs well and character values can be embedded within the students. The roles of teachers in the reinforcement of students' character education are important because teachers hold the control of students' character achievement. Teachers of SMK Muhammadiyah 1 Wates apply TADZKIROH model (Show the Example, Drive, Zakiyah or Embed sincere intention, Continuity, Remind, Repetition, Organize, and Heart)in the implementation of students' character education from Islam education perspective. By giving an example to students, guidance, motivation, embedding a sincere intention, inculcating 
process of studying and performing good action, reminding in goodness, performing repetition, organizing, and touching the students' heart, so teachers will shape and reinforce students' character.

\section{REFERENCES}

1. Aeni, A. N. (2014). Pendidikan Karakter Untuk Siswa SD dalam Perspektif Islam. Mimbar Sekolah Dasar, 1 (1), 50-58. https://doi.org/10.1016/S0022-0248 (02)021486

2. Ainiyah, N. (2013). Pembentukan Karakter Melalui Pendidikan Agama Islam. AlUlum, 12 (1), 25-38.

3. Anaas Tri Ridlo Dina Yuliana, S. (2017). Peran Kepemimpinan Pendidikan Islam dalam Manajemen Perubahan pada Lingkungan Organisasi Pendidikan di Madrasah Ibtidaiyah An-Nuur, Ngangkrik Triharjo Sleman. Tadris, voleme 12 (2).

4. Creswell, J. W. (2012). Educational Research: Planning, Conducting, and Evaluating Quantitative and Qualitative Research. Pearson Education.

5. Darimi, I. (2017). Teknologi Informasi dan Komunikasi Sebagai Media Pembelajaran Pendidikan Agama Islam. Jurnal Pendidikan Teknologi Informasi, 1 (2), 111-121. https://doi.org/10.1007/s11068-008-9037-4

6. Fahrudin, Asari, H., \& Halimah, S. (2017). Implementasi Kurikulum 2013 Pendidikan Agama Islam dan Budi Pekerti dalam Menanamkan Akhlakul Karimah Siswa. Edu Riligia, 1 (4), 516-531.

7. Fitri, A. (2018). Pendidikan Karakter Perspektif Al-Qur'an Hadits. TA 'LIM: Jurnal Studi Pendidikan Islam, 1 (2), 258-287.

8. Hamdani, D. Al. (2014). THE CHARACTER EDUCATION IN ISLAMIC EDUCATION VIEWPOINT. Jurnal Pendidikan Islam, 1 (1).

9. Hasnawati. (2020). Implementasi Model Pembelajaran Tadzkirah Pada Pelajaran Aqidah Akhlak di Madrasah Ibtidaiyah (MI) Nurul Jihad Kecamatan Tembilahan Hulu. Jurnal Pendidikan “EDUKASI," 8 (1), 64-77.

10. Herwina, I. dan. (2018). Penguatan Pendidikan Karakter Perspektif Islam dalam Era Millenial IR. 4.0. Membangun Sinergitas Dalam Penguatan Pendidikan Karakter Pada Era IR 4.0, 1 (1), 21-42.

11. Islam, S. (2017). Karakteristik Pendidikan Karakter; Menjawab Tantangan Multidimensional Melalui Implementasi Kurikulum 2013. Edureligia; Jurnal Pendidikan Agama Islam, 1 (1), 89-100. https://doi.org/10.33650/edureligia.v1i2.50 
12. Majid, A., \& Andayani, D. (2012). Pendidikan Karakter Perspektif Islam. Remaja Rosdakarya.

13. Ninsiana, W. (2016). Kontribusi Model Tadzkirah dalam Pengajaran dan Pembelajaran Bahasa Inggris Berkarakter Pada Anak Usia Dini. Elementary, 2 (2), 1-13.

14. Pawitasari, E., Mujahidin, E., \& Fattah, N. (2015). Pendidikan Karakter Bangsa dalam Perspektif Islam (Studi Kritis Terhadap Konsep Pendidikan Karakter Kementerian Pendidikan \& Kebudayaan). Ta'dibuna: Jurnal Pendidikan Islam, 4 (1), 1-21. https://doi.org/10.32832/tadibuna.v4i1.573

15. Ramdhani, M. A. (2014). Lingkungan Pendidikan dalam Implementasi Pendidikan Karakter. Jurnal Pendidikan Universitas Garut, 8 (1), 28-37. https://doi.org/10.1177/002218568402600108

16. Ridwan. (2017). Model Tadzkirah Dalam Menumbuhkan Dan Mengembangkan Nilai Nilai Karakter Anak Usia Dini. Efektor, 4 (1), 44-53.

17. Rostikawati, Y., Aeni, E. S., \& Wuryani, W. (2020). Peran Guru Dalam Membentuk Karakter Siswa Melalui Pembelajaran Kesantunan Berbahasa Di Media Sosial. Abdimas Siliwangi, 03 (01), 112-120.

18. Suryadarma, Y., \& Haq, A. H. (2015). Pendidikan Akhlak Menurut Imam Al-Ghazali. At-Ta'dib, 10 (2), 362-381.

19. Suryanti, E. W., \& Widayanti, F. D. (2018). Penguatan Pendidikan Karakter Berbasis Religius. Conference on Innovation and Application of Science and Technology (CIASTECH 2018), September, 254-262.

20. Warsito. (2017). Peningkatan Sikap Kedisiplinan melalui Apel Pagi Siswa MIN Nglawu Sukoharjo. Jurnal Komunikasi Pendidikan, 1 (2), 155-161.

21. Widayat, D. P. (2016). Keefektifan Peer Support Untuk Meningkatkan Self Discipline Siswa SMP. Jurnal Konseling Indonesia, 2 (1), 1-9.

22. Yuliana, A. R., \& Wurinta, A. R. (2020). Manajemen Strategi Pembelajaran dalam Membentuk 9 Pilar Karakter di Playgroup MILAS. Jurnal PG-PAUD Trunojoyo: Jurnal Pendidikan Dan Pembelajaran Anak Usia Dini, 7 (1), 37-46. 